Portland State University

PDXScholar

1971

\title{
The effects of sociological theories of poverty on job training programs
}

Michael Richard DeShane

Portland State University

Follow this and additional works at: https://pdxscholar.library.pdx.edu/open_access_etds

Part of the Community-Based Research Commons, and the Work, Economy and Organizations Commons

Let us know how access to this document benefits you.

\section{Recommended Citation}

DeShane, Michael Richard, "The effects of sociological theories of poverty on job training programs" (1971). Dissertations and Theses. Paper 1540.

https://doi.org/10.15760/etd.1539

This Thesis is brought to you for free and open access. It has been accepted for inclusion in Dissertations and Theses by an authorized administrator of PDXScholar. Please contact us if we can make this document more accessible: pdxscholar@pdx.edu. 
AN ABSTRACT OF THE THESIS OF Michael Richard DeShane for the Master of Arts in Sociology presented July 23, 1971.

Title: The Effects of Sociological Theories of Poverty on Job Training Programs.

APPROVED BY MEMBERS OF THE THESIS COMMITTEE:

$$
\text { Leonard Cain, Jr., Chairmán }
$$

$$
\text { Wilson Record }
$$

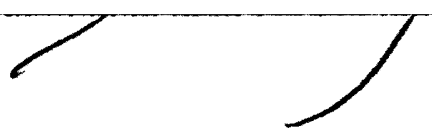

\section{Barry Lebowitz}

This thesis is an exploratory study of the effects of two job training programs for the poor in Portland, Oregon. It seeks to illustrate that training programs are designed around certain theoretical conceptions or models of poverty and that these theoretical conceptions ultimately have a strong effect on the enrollees in programs designed on the given theoretical model. Two general theoretical models have been extracted from the literature. The first is the "Culture of Poverty" model and the second may be called the "Closed Opportunity Structure" model. 
The culture of poverty model posits that the poor are unable to escape poverty because of certain cultural aspects of their conditions which inhibit them from taking advantage of increased opportunities when they are offered them. Some of the major aspects of the culture of poverty are: (1) The poor do not share the values of the dominant culture, e.g., that hard work brings rewards, and deferring immediate gratification also produces future rewards; (2) The poor do not participate fully in the major institutions of the society; (3) The Inability to take advantage of increased opportunities is learned through the parents; and (4) This inability tends to perpetuate the culture of poverty.

The closed opportunity model, on the other hand, posits that the poor do indeed share the values of the dominant culture but that they have been denied the opportunity to realize these values, i.e., the poor do not defer gratification because even if they did so their chances of receiving a future reward are low. The closed opportunity structure model sees the problems of the poor as being grounded in the larger society as opposed to being inherent deficlencies of the poor themselves.

I have selected two programs for this study on the basis of their subscription to one or the other theoretical models discussed above. Portland Residential Manpower Center (PRMC), an urban Job Corps camp, was chosen because its program design conforms to the culture of poverty model in that it attempts to resocialize the trainee so that he may better fit into the society; conversely, the Portland New Careers Project 
was chosen because it subscribed to the closed opportunity model in that it does not see these socialization attempts as necessary, but rather, it places its trainees in social service positions with various governmental agencies and provides them with education which, hopefully, will enable the trainee to move into a more professional position at the agency. The study then attempts to describe the effects of each of these programs on its enrollees.

The method of direct observation was chosen for several reasons: (1) The exploratory nature of the study; (2) The absence of a clear cut hypothesis to test; (3) Inadequate statistical data available which would give me answers to the kinds of questions I had asked.

The findings indicated that the two programs had very different effects on the enrollees. PRMC, because of its highly structured character and complete program of socialization, produced a high degree of distrust of the program on the part of the trainees. PRMC's socialization attempts were seen as largely unnecessary by the trainees and they felt that these attempts interfered with the primary task of skill training. New Careers, on the other hand, lacks a highly structured program. Aside from being expected to put in time at the placement agency and to attend his classes, the trainee is left largely on his own. This almost complete lack of structure has made it exceedingly difficult for many of the trainees to progress in the program because they have few guidelines for theix training. The New Careerist learns what is expected of him through trial and error.

The findings of this study suggest that social scientists should be aware of the consequences of their theoretical models on the people 
these models attempt to deal with. Both programs studies exhibited deficiencies which, in varying degrees, are the result of the theoretical models upon which the program is based. 
THE EFFECTS OF SOCIOLOGICAL THEORIES OF POVERTY

ON JOB TRAINING PROGRAMS

by

MICHAEL RICHARD DESHANE

A thesis submitted in partial fulfillment of the requirements for the degree of

MASTER OF ARTS

in

SOCIOLOGY

Portland State Univrrsity

1971 
TO THE OFFICE OF GRADUATE STUDIES:

The members of the Comnittee approve the thesis of Michael Richard DeShane presented July 23, 1971.

Leonard Cain, Jr., Chairman

Wilson Record

Barry Lebowitz

APPROVED:

Leonard Cajin, Jr., Head, Department of Sociology

Dávid T. Clark, Dean of Graduate Studies

July 27,1971 
TABLE OF CONTENTS

PAGE

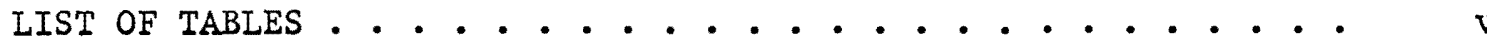

CHAPTER

I DIFFERENTIAL EFFECTS OF OPPOSING THEORETICAL

MODELS OF POVERTY ON THE DESIGN OF REMEDIAL

TRAINING PROGRAMS FOR THE POOR . . . . . . . . . . . I I

The "Culture of Poverty" Model and

Job Corps . . . . . . . . . . . . . . . 2

The "Closed Opportunity Structure"

Model and New Careers . . . . . . . . . . 6

II METHODS AND GOALS OF THE RESEARCH . • . • • • • • • • 11

Sample Differences . . . . . . . . . . 13

Selection Processes . . . . . . . . . . . 16

Operationalizing the Theoretical Model . . . . 18

II THE PROGRAMS . . . . . . . . . . . . . . . . . 19

Portland Residential Manpower Center

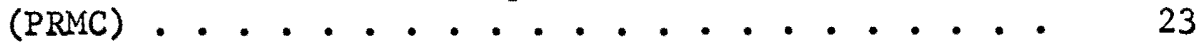

Portland New Careers Project. . . . . . . . 28

IV FINDINGS . . . . . . . . . . . . . . . 32

Portland Residential Manpower Center

(PRMC): A Matter of Respect . . . . . . . . 32

New Careers: A Matter of Structure . . . . . 42

The New Careerist as Staff at PRMC . . . . . 50

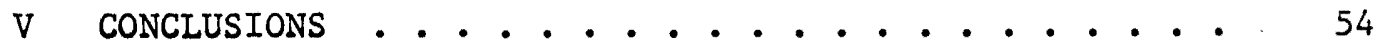

REFERENCES . . . . . . . . . . . . . . . . . . . 61 


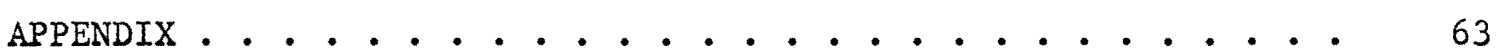

Results of Group Meetings ............ 63 


\section{LIST OF TABLES}

TABLE

PAGE

I Theoretical Notions of the "Culture of Poverty" Model and Those Aspects of the Job Corps Designed to Ameliorate those Notions . . . . . . . . .

II Theoretical Propositions of the "Closed Opportunity Structure" Model and Those Aspects of New Careers Designed to Ameliorate Those Propositions . . .

III Sample Differences in Terms of Trainee Attributes. . . 
CHAPTER I

DIFFERENTIAL EFFECTS OF OPPOSING THEORETICAL MODELS OF POVERTY ON THE DESIGN OF REMEDIAL TRAINING PROGRAMS FOR THE POOR

In March, 1964, hearings began in the House of Representatives of the United States on a so-called war on poverty which was proposed by President Johnson. As a result of these hearings poverty became one of the nation's primary concerns. The Office of Economic Opportunity was created to plan and organize the administration of a wide range of programs designed to aid the poor and, hopefully, to help them escape from the conditions of poverty. Michael Harrington's book, The Other America (1962), is generally credited with providing the impetus for attack on poverty (Seligman, 1968). Harrington dramatically pointed out that al though America is indeed a rich country, a significant portion of its citizens continue to live in poverty. Harrington's book dealt with the effects of poverty as no statistics could and brought to light a problem which we have long had but seldom noticed. Poverty was not new to this country; the New Deal had attempted to deal with the problems of poverty, but the New Deal was designed around a highly visible poverty population. Our increasing Gross National Product following the New Deal tended to hide the poor that were still existing in this country. Most citizens apparently forgot about the remaining poor. The Corgressional hearings of 1964 began to change this and poverty became, after a lapse of a quarter century, an issue for the federal government.

Since the war on poverty was begun in the early $1960^{\prime}$ 's a great deal 
of work has been done in an attempt to understand the problems and needs of the poor and to develop programs which could make gains toward the elimination of this problem. Providing training for productive careers for the hitherto unemployable people in the society was one of the major goals of these programs, for without steady jobs the poor had little hope of lifting themselves from their dependency upon others. But simple skill training alone was not considered sufficient to overcome the deeply ingrained life styles of the poor. Poverty appeared to manifest myriad other problems aside from a low level of employment and any training program would have to take into account these other problems if it was to be successful. Programs were designed around theoretical models concerning the nature and extent of poverty in the United States and the program designed depended upon the model the designers subscribed to. There are currently two general theoretical models of poverty which can be extracted from the 1iterature. One is the "Culture of Poverty" mode1 and the other is what may be called the "Closed Opportunity Structure" nodel. There are currently in operation training programs which subscribe to each of these views. The purpose of this thesis is to identify the essential theoretical aspects of each of these views, to describe the training programs which have been designed around the two theories, and to assess the effectiveness of each theory and its related program in waging the war on poverty.

THE "CULTURE OF POVERTY" MODEL

The term culcure of poverty was coined by Oscar Lewis (1959), during his presentation of the results of anthropological studies in 
Mexico. Many others have since used Lewis' basic propositions in studies of poverty in America (Harrington, 1962; Moynihan, 1965). "The Cu1ture of Poverty" model posits the hypothesis that the poor manifest a different set of values, attitudes and beliefs from that of the larger society and that this set of values, attitudes and beliefs makes up a distinct cultural tradition which runs counter to that of the larger society and perpetuates itself through socialization of the children. In Lewis' words:

Once it [the culture of poverty] comes into existence it tends to perpetuate itself from generation to generation because of its effect on children. By the time slum children are age six or seven they have usually absorbed the basic values and attitudes of their subculture and are not psychologically geared to take full advantage of changing conditions or increased opportunities which may occur in their 1ifetime (Lewis, 1968, p. 263. Stress mine).

Harrington states that the culture of poverty exists also because of a network of problems which, when put together, makes up a complex pattern of life from which there is 1jttle chance of escape without massive assistance.

In short, being poor is not one aspect of a person's life in this country, it is his life. Taken as a whole, poverty is a culture. Taken on the family level it has the same quality. These are people who lack education and skill, who have bad health, poor housing, low levels of aspiration and high levels of mental distress (Harrington, 1962, p. 158).

Other aspects of the culture of poverty are: (1) The poor fail to par-ticipate in the larger society and lack organizational abilities (Lewis, 1968; Weller, 1966; Harrington, 1962); (2) The poor are unable to defer gratification (Davis, 1949; Schneider and Lysgaard, 1953); and (3)

The family system of the poor is considered dysfunctional (Lewis, 1959; Moynihan, 1965). Therc are, to be sure, many aspects of poverty which 
could easily be used by culture of poverty theorists and, indeed, have been used. Such aspects as lack of motivation, inability to relate using language and low self-esteem all have, at various time, been put into the culture of poverty bag, but, be that as it may, the major aspects of the theory have been presented above in a general sense.

The culture of poverty theory takes the position that the poor have an entirely different outlook on life from those in middle-class America. The poor do not share the values and aspirations of the larger society; hence, even if given the opportunity to escape from poverty they would be unable to take advantage of the opportunity because of their own distinct cultural background. If we are to eradicate poverty we must make an attempt to alter the culture of poverty; the poor must be resocialized to the dominant culture if they are to escape the grip of the culture of poverty; and any training program which does not take this factor into account is doomed to failure, according to the culture of poverty theorists. In the culture of poverty theory the poor inhabit a social realm which is dysfunctional to their success in the dominant culture. Through the culture of poverty theory we effectively blame the poor themselves for their shortcomings and it becomes a matter of reforming the poor so that they may take their place in society.

In 1964 the United States began the Job Corps as an ambitious job training program for young people who were unable to get work. The theory behind the Job Corps was that if the disadvantaged youth could be renoved from an environment which inhibited success and could be provided with shelter, food, medical care, a healthy soctal environment and a little extra spending money along with skill training, he would have a chance to break out of the cycle of poverty he was a part of or 
was on his way to becoming a part of. The Job Corps took the culture of poverty concept to a practical level. Individuals who joined the Job Corps were taken hundreds or even thousands of miles from their homes where they would be free, hopefully, of the unhealthy social environment of their childhood. The corpsman was given training in all aspects of 1ife. Table I points out certain notions of the culture of poverty theory and those ameliorative aspects of the Job Corps which were designed to meet these notions.

Following completion of the program at the Job Corps camp the trainee should have not only a set of skills with which he can compete for a job but a new outlook on life which will enable him to participate in middle-class society to a fuller extent. He will have developed a set of values and attitudes conducive to success in the larger society. The Job Corps strategy illustrates we11 how a theoretical mode1, in this case that of the culture of poverty, can guide the design of a training program. In summary, the Job Corps is based generally upon the culture of poverty theory and is designed to ameliorate those aspects of poverty which inhibit full participation in the larger society by the poor. We will now look at the other side of the coin and at a program designed around a different theoretical conception of poverty.

THE "CLOSED OPPORTUNITY STRUCIURE" MODEL

The closed opportunity structure view does not hold with the culture of poverty model in several important respects. First, this model holds that the poor do indeed share the basic values of the dominant society. They differ not in their values but only in the means toward which those values are realized. Merton (1968) in "Social Structure and 
TABLE I

THEORETICAL NOTIONS OF THE "CULTURE OF POVERTY"

MODEL AND THOSE ASPECTS OF THE JOB CORPS

DESIGNED TO AMELIORATE THOSE NOTIONS

THEORETICAI NOTIONS OF

THE CULTURE OF POVERTY THEORY

\section{SPECIFIC AMELIORATIVE \\ ASPECTS OF THE JOB \\ CORPS}

The culture of poverty encompasses the entire iffe situation of the poor.

The poor have a value system different from that of the dominant culture.

The poor are non-participatory in the larger society and lack organization.

The poor lack resources and skills which would enable them to enter the larger society.
Individual is removed from this environment.

Teach the corpsman new values through classes, group meetings, counseling and example.

Work with the corpsmen as a group and teach them the benefits of organization.

Train the corpsman in job skills so that he may become a productive member of society. 
Anomie" pointed out that the way an individual pursues a goal is dependent upon those means he is capable of using. If the poor share the basic values of the rest of the society but are denied the traditional modes of access to realizing those values, then, they will adjust to these circumstances and seek realization of these values through alternate channels; hence, rather than viewing the poor as making up a dysfunctional subculture they are viewed as functionally adapting to conditions imposed upon them by the larger society. Miller and Riessman (1965) used the deferred gratification pattern to show the error of attributing any basic differences between the poor and the rest of society as regards the ability to defer gratification. Early poverty theorists suggested that one of the patterns of behavior which the poor had which was dysfunctional to success was their inability to defer gratification and that this carpe diem attitude kept them from achieving any sort of stability in the society (Davis, 1949; Schneider and Lysgaard, 1953). Miller and Riessman, however, point out that in order to make any use of this concept several conditions must be met.

1. The two class groups must equally value the satisfaction that is being deferred . . .

2. The two class groups must have an equal understanding and opportunity to defer an immediate gain for a future reward ....

3. The two class groups must suffer equally from the deferment . . .

4. The two class groups must have the same probability of achieving the gratification at the end of the deferment period . . . (Miller and Riessman, 1965, p. 290).

Clearly these conditions are seldom, if ever, met. The poor know that in most cases if they defer gratification, their chances of achieving the satisfaction they are deferring are practically non-existent. The poor do not defer gratification because their experience has told them 
that if they are to get anything at all, it must be taken whenever the opportunity presents itself. According to the closed opportunity structure model this is not a cultural phenomenon but an adjustment to conditions externally imposed upon the poor. The closed opportunity structure model holds that the poor have learned through repeated frustrations that they must adapt themselves to the situation and seek gratification In ways different from those of the middle class. Only through continual positive experiences can this be changed. If the general outlook of the poor is to be changed it can only be done by providing these positive experiences. Liebow sums up this view of the closed opportunity model quite we11 when he states:

- . the street corner man does not appear as a carrier
of an independent cultural tradition. His behavior appears
not so much a way of realizing the distinctive goals and
values of his own subculture, or of conforming to its
models, but rather as his way of trying to achieve many of
the goals and values of the larger society, of failing to
do this, and of concealing his failure from others and from
himself as best he can (Liebow, 1967, p. 222).

A second way the closed opportunity model differs from the cu1ture of poverty model is that the blame for poverty is placed on the larger society rather than on the poor. The poor behave as they do not because of any subcultural view of the world but because they are forced, by the larger society, to behave as they do. The society has denied the poor access to the goodies of the society, but they still want these goodies so they go after them in unconventional ways. We do not alleviace poverty by changing the poor to conform to general societal standards of behavior, rather we must widen the opportunity structure to an extent that the poor are no longer denied access to the ways and means of achieving success in this society. Implicit in 
this view, of course, is that the poor will change as a result of this widened opportunity structure; however, the change will initially be in the larger society and the poor will take care of themselves. We cannot change the poor without first changing the opportunity structure and if we change that structure we need not worry about the life styles of the poor.

There has been some empirical evidence to support this view of poverty. Gurin (1968) in a study of a JOBS project in Chicago, found that when the trainee had a job during his training period he was more likely to achieve success in the training program; furthermore, social psychological measurements of value orientations found that there was no significant difference between the trainees and the staff of the project on those measurements. Coleman (1966) in his huge study of educational opportunity, found that black students basically held the same hopes and aspirations as the white students but that they felt that their chances of achieving these hopes and aspirations were not the same as the white students.

We can now extract two major points which must be taken into account when designing a training program according to the closed opportunity structure model.

1) The trainee should have a meaningful jos with possibilities for upward mobility. This job must be personally rewarding to the trainee as it must combat the trainee's history of continual failure and lack of control over his life situation.

2) The opportunity structure must be altered to make 
room for the poor rather than attempt to adjust the poor to the condjtions imposed by the current opportunity structure. If the poor chat.ge it will not be through changing their values but through altering the opportunity structure.

A program currently in operation which subscribes to the closed opportunity structure model is the New Careers program. The idea behind New Careers is to train the poor for jobs in human services. Many jobs currently being performed by professionals could well be performed by non-professionals. Ideally the poor could begin as aids to professionals and through training move up the ladder ultimately to become a professional himself. The general goals of the New Careers program have been set down by Pearl and Riessman:

1. A sufficient number of jobs for all persons without work.

2. The jobs to be defined and distributed so that place-ments exist for the unskilled and uneducated.

3. The jobs to be permanent and provide opportunity for life-long careers.

4. An opportunity for the motivated and talented poor to advance from low-skill entry jobs to any station available to the more favored menbers of society.

5. The work to contribute to the we11 being of society (Pearl and Riessman, 1965, p. 2).

Pearl and Riessman further state that:

The New Career proposal is a call for wholesale change. It is likely that every institution of our society would be affected. Education, employment practices and recruitment, welfare, administration of health services - all would be greatly influenced if the New Careers program were instituted (Pearl and Riessman, 1965, p. 21).

From the discussion above it can be seen that the New Careers proposal meets the two major contingencies of the closed opportunity structure model and Table II illustrates the extent to which this is so. First 
TABLE TI

THEORETTCAT, PROPOSITTONS OF THE "CLOSED OPPORTUNITY STRUCTURE" MONIL AND THOSE ASDECTS OF NEW CAREERS DESTGNED

TO AMELIORATE THOSE PROPOSITIONS

CI.OSEI) OPPORTUNTTY STRUCTURE

NEW CAREERS PROGRAM MODEL,

The poor share the general values of the midile class and only lack the opportunity to pursue those values

The structure of our society is such that the poor have. been denied cpportunities to gain entry into meaning.ful occupations
New Careers provides the trainee with a meaningful job in social service with advancement opportunities

New Careers attempts to alter: the structure of the social service agencies so that the poor can succeed in these agencies as employees 
the New Careers proposal explicitly states that a meaningful job is the first requirement of any training progran and second that society's institutional and occupational structures must be altered to accept the poor.

The two models, culture of poverty and closed opportunity structure, discussed above are meant to subsume a host of other descriptive models assigned to the poor. It is my belief that views of the poor, such as the undeserving poor, the disadvantaged poor and the exploited poor can all be included within one of the two frameworks presented here. We can either deal with the poor as though there is something wrong with them (culture of poverty) or we can deal with the society as though there is something wrong with it (closed opportunity structure). However we choose to view the poor it would seenl logical to assume that that view will have ramifications for remedial training programs and the people those programs are designed to help.

There have been numerous evaluative studies of job training programs, but these studies have been aimed primarily at determining levels of success or failure of the individual programs under study. To my knowledge there has been no study which attempts to relate how certain theoretical beliefs about the individuals being trained affect that individual's adjustment to the program's goals and methods of operation. It is my intent in this study to uncover how program design and operation affect the traince's ability to adjust to the new set of demands for which he is being trained; in other words, I am interested in gaining some understanding as to how the trainee behaves and what kinds of changes take place in the trainees under programs which take a radically different view as to the needs of those trainees. 
Theoretical models and their relationship to actual situations is a little studied phenomenon. Poverty theory provides a rare opportunity to examine this relationship, since most other theoretical models are quite divorced from the activity they purport to explain. With poverty theory we have two rather distinct theoretical orientations, both of which have been translated into remedial programs and it is one of the few areas where we can see opposing theoretical orientations being applied toward the same ends. This gives us an opportunity to look at the consequences of these models. This has, to my knowledge, not been done before; hence, there are no existing studies from which we may borrow a research model with which to interpret the consequences of these theoretical models. I have therefore kept the research design as open-ended as possible, using data from any source I felt would help to explain how these models affected the people they were designed to help. This study, therefore, is not as methodologically rigorous as might have been the case had I merely chosen a few indicators which I felt reflected the attitudes of the trainees, acquired a measure of these indicators and sought to explain success rates of the programs therefrom. Instead, my indicators have been developed through observation; and I will attempt also to gain a measure of them through observation. Again, my interest is primarily directed toward uncovering general tendencies of each of the theoretical model's application and to relate this to trainee attitude and behavior rather than to present any sort of definitive statement concerning student-staff relationships. 
This thesis is an exploratory study of two job training programs for the poor in Portland, Oregon. Its major purpose is to determine how theoretical models effect the trainees in the programs. I have chosen two programs, the Portland Residential Manpower Center (PRMC) which is an urban Job Corps Camp, and the Portland New Careers program. These two programs were chosen for study primarily because of the opposing theoretical models behind each of the programs as explicated in Chapter I. In actuality nejther PRMC nor New Careers represents the ideal types of the models presented above. Each of the programs appears to contain certain aspects of both the culture of poverty model and the closed opportunity structure model. As an example, near the end of the training period at PRMC students receive several weeks of job experience while still technically enrolled at PRMC. The noed for this experience as determined by the staff shares many of the theoretical concerns of the closed opportunity structure model. The job experience segment of the training is designed to show the student that he can succeed in the world of work and that he doesn't have to fail continually. This is based on the idea of reinforcing or strengthening the student's self-conception. Similarly New Careers attempts in group counseling sessions to instill attitudes conducive to success on the job. Both of these examples tend to move the respective programs toward the other's basic model; however, closer examination reveals 
that these examples do not alter the fact that the two prograns are based on quite different theoretical tenets. PRMC does not give the work experience until after the student has been in the program for a considerable time and hopefully after the student has learned a new set of attitudes and beliefs conducive to successful completion of the work experience period of his or her training; likewise, the counseling sessions at New Careers are relatively unorganized and deal primarily with problematic aspects of the students training as opposed to any kinds of general attitude alteration. We have, then, two training programs which are theoretically a considerable distance apart. Each program attempts to translate these theoretical conceptions into a working model. The differential effects of these contrasting working models on the trainees remains to be considered.

I have chosen, primarily, the observational method of research for several reasons:

1) The exploratory nature of the study required a relatively unstructured type of method so that I could follow up any research leads I found during the study. I had to be ready to flow with the discoveries about the programs as it were;

2) I had no clear-cut hypothesis to be tested and aimed only at an understanding of the general tendencies exhibited by each program and how these programs affect the trainee, and;

3) There are few measures or statistical data available which will give me answers to the kinds of questions I have asked. 
In addition to my observational data I have sought to reinforce my analysis with published studies and materials distributed by the programs themselves. Some publications of PIMC have been very important, especially a report on their "Seminar for Improvement, " $*$ which consisted of an entire week's discussion by students and staff about various problems with the prograin. (The fact that this seminar was designed to remove the students from Portland during the American Legion convention during the Summer of 1970 is interesting and important as will be seen.) I vill also make use of the Student's Handbook for PRMC trainees and various papers and reports put out by the New Careers program in Portland. The data generated from the observations and publications are typically not specific; rather, the data will largely be in the form of examples of general kinds of tendencies which I feel reflect how the theoretical model of the program affects the attitudes of the trainee. The types of data available do not permit statistical testing so I have no plans of using statistical validity to check on my conclusions; rather, I will attempt to support my conclusions through relating examples which I believe to represent a connection between a trainee's attitudes and behavior on the one hand and the beliefs concerning the poor of the staff and program designers on the other. There are of course a number of methodological difficulties involved which inhibit any kind of direct comparison of the two programs and which tend to increase the difficulties of analysis. I will here attempt to explicate these problems and

*The seminar was held at the Springdale campus outside of town. The girls were taken out by bus each morning from their residence hall in town and returned each evening. 
to resolve them as best I can.

\section{Sample Differences}

The two programs are quite different with respect to trainee attributes. Table II gives a brief statistical breakdown of the trainees in each program and it can be seen from this table that the trainee populations of the programs are considerably different. The average PRMC trainee is white, between 16 and 20 years o1d, and has not finished high school, whereas the new careerist tends to be black, 27 years old, and a higher proportion have completed high school.

Had I wished merely to undertake a comparative study of the two programs in terms of success rates, these sample differences might well have prohibited such a study; however, since my goal is to illustrate the consequences of differing theoretical designs on trainee attitudes and behavior and on the general operation of each program, the sample differences may well be illustrative of the translation of these differing theoretical models into the respective training programs. The culture of poverty model stresses the importance of cultural transmission from parents to offspring and it follows from this that if any program hopes to make any gains toward the interruption of this transmission then age may well be an important factor; the younger the trainee is the more success one will have in breaking this cycle of cultural transmission. In accord with this belief PRMC concentrates its efforts on individuals from 16 to 21 ycars of age, prohibiting olaer individuals from entering the program. New Careers, on the other hand, has no age linitation. The New Careers program will and does accept much olcier people for training. This willingness to accept older trainees into the program is in 
TABLE II

SAMPLE DIFFERENCES IN TERMS OF TRAINEE ATTRIBUTES

\begin{tabular}{|c|c|c|c|c|}
\hline . & $\begin{array}{l}\text { PORTLAND RESII } \\
\text { MANPOWER CEI }\end{array}$ & & $\begin{array}{l}\text { NEW C } \\
\text { PRO }\end{array}$ & \\
\hline $\begin{array}{l}\text { Number of } \\
\text { Trainees in } \\
\text { Program as of } \\
\text { Fal1, } 1970\end{array}$ & & 183 & & 66 \\
\hline $\begin{array}{l}\text { Mean Age } \\
\text { on Entering } \\
\text { Program }\end{array}$ & & 17.4 & & $27 *$ \\
\hline Sex Ratio & $\begin{array}{l}\text { Male } \\
\text { Female }\end{array}$ & $\begin{array}{l}47.6 \% \\
52.4 \%\end{array}$ & $\begin{array}{l}\text { Male } \\
\text { Female }\end{array}$ & $\begin{array}{l}35.0 \% \\
65.0 \%\end{array}$ \\
\hline Race & $\begin{array}{l}\text { Caucasian } \\
\text { Black } \\
\text { Other }\end{array}$ & $\begin{array}{r}80.9 \% \\
13.1 \% \\
6.0 \%\end{array}$ & $\begin{array}{l}\text { Caucasian } \\
\text { Black } \\
\text { Other }\end{array}$ & $\begin{array}{r}18.5 \% \\
80.0 \% \\
1.5 \%\end{array}$ \\
\hline Education & $\begin{array}{l}\text { Without High } \\
\text { School Complete } \\
\text { With Diploma } \\
\text { or G.E.D. }\end{array}$ & $\begin{array}{l}92.9 \% \\
7.1 \%\end{array}$ & & $* *$ \\
\hline
\end{tabular}

* I have used the median age for New Careers because of wide range of ages.

**These statistics were not readily available. Almost all of the first cycle New Career people were without high school completion, but the later trainees tend to have a higher rate of high school completion. I would afpreximate that about $20 \%$ have either a diploma or G.E.D. 
accord with the closed opportunity structure model, in that the model does not explicitly differentiate the poor in terms of age. older people lack opporturities, at least to as great an extent as do young people; therefore, New Careers does not use age as a factor in the selection of trainees.*

The racial differences between samples can partly be accounted for because of the geographical. areas served by the two programs. The New Careers progratn must take its trainees from the area served by the Concentrated Employment Program** which is a predominantly black area of the city. PRMC, on the other hand, can recruit trainees from the entire Portland area; hence, PRMC contains a much larger proportion of whites than does New Careers.

\section{Selection Processes}

The New Careers selection process appears to be somewhat more demanding than that at PRMC. New Careers cannot handle as many trainees as can PRMC; furthermore, the popularity of the New Careers program and nature of the work for which training is directed are such that the staff members feel they should be somewhat more selective than regular job training programs. As an example, New Careers requires that the trainees have at least a fair educational background. They should be able to read and write comprehensively because of the nature of the work for which they are training. New Careers had a bit of trouble with the

\footnotetext{
* New Careers does prohibit very young people from entering the program because of the legal difficulties involved.

**The Concentrated Employment program is a nationwide, federally funded employment service for ghet to youth.
} 
first group of students because of educational deficiencies which prohibited them from making any real progress in the program. The New Careers staff has since revised their entrance requirements to avoid this problem. PRMC, on the other hand, does not select on educational deficiencies and would admit an individual who had been rejected by New Careers. I do think that selection processes may well affect the expectations of the staff and hence affect the way in which the staff deals with its trainees. This may be a serious intervening variable in my research; however, it may also reflect the theoretical orientation upon which the program is designed. If you think the poor are in bad shape to begin with, you don't require high standards for acceptance into the program. Whatever the case may be, I have attempted to account for this possible problem during my data collection by discussions with the teachers in both programs as to the expectancies they have for their students and have found that the teachers at PRMC are quite satisfied with the abilities of their students as a whole, but, of course, wish that they were more motivated. In contrast, New Careers instructors who teach beginning college courses tend to lighten the load or revise their grading standards for their students because they believe the demands of the work involved in a standard college course may be beyond the capabilities of those enrolled. From my observations of the students I have come to the conclusion that for the most part the student at PRMC is as prepared intellectually as is his counterpart at New Careers. I do not therefore believe that the selection processes of the respec- 
tive programs are as crucial to the study as they first appear.*

\section{Operationalizing the Theoretical Mode1}

The most difficult problem I have faced in this study has been the translation or operationalization of the theoretical models of each program into observable manifestations of the effect of these models on the trainee. I have no readily usable operationalizations and have attempted to use student-staff relations as a guide. I have no strong methodological support for using student-staff relations as an indicator of how these theoretical models affect the trainee; rather, the connection can only be made logically, based on observation of the programs in action. The needs of the trainee as perceived by the staff are important elements of communication between the staff and the trainees. If a staff member feels that the trainee is leading the wrong kind of life because he has not yet learned the proper way to behave and, furthermore, that he is unmotivated, he is likely to communicate these feelings to the student and the student will react openly to these communications from the staff, either by agreeing with the staff

*See Miller, et. a1., "Creaming The Poor," TransAction, June, 1970 for a discussion of selection processes of poverty programs as a whole which raises some serious questions concerning the effectiveness of all poverty programs.

The authors contend that poverty programs tend to select out or "cream" only the most promising of the poor because these programs are more interested in successful results than in helping those who need help most. The result of this "creaming" is the selection of trainees who might well have been successful without the program and the denial of service to those whose chances for success axe slim. 
appraisal or by rejecting them. However, if the staff thinks that there is nothing wrong with the trainee except that he has been denied fulfillment of his gcals then, this too, will be communicated to the trainee and will affect his behavior within the program. I see no way in which to translate the theoretical orientations of the staff into observable phenomena other than through student-staff relations. Social psychological measurements generally say nothing about theoretical orientations and tend to concentrate entirely upon attributes of the individuals being tested. I have, therefore, concentrated my observations on problematic aspects of student-staff relations with the hope that this concentration may shed some light on the consequences of transposing a given theoretical explanation into a working model with real actors. 


\section{CHAPTER III}

\section{THE PROGRAMS}

Portland Residential Manpower Center (PRMC)

PRMC is an urban Job Corps Center run by the Portland Public School System under contract with the Federal Government. PRMC has been in operation since March of 1970. The objectives of PRMC can be subdivided into three main areas:

1) Skill training

2) Basic Education

3) Socialization

The primary objective of PRMC is to train the incoming student in the skills necessary to obtain an entry level position in any of a number of general occupational categories. In a student's handbook published by the center the goals of the program are briefly explicated:

The specific task of the Center is to assist and make employable those young people of the larger metropolitan area for whom the familiar and established programs of education and vocational training have not been adequate or successful. The training program of the Center will endeavor to meet the specific needs of the individual student assuring their development of an occupational skill and entry into the job force (Student's Handbook, p. 1).

The training at PRMC is directed toward skills for which there are likely to be job openings and which are non-technical. The student can choose from a number of occupational categories such as mechanics, electronics, and business skills which he finds interesting. The training is nontechnical in that it is aimed at teaching only those basic skills nec- 
essary for an entry level position. The Center does not, for example, train the pupil to be a qualified auto mechanic; rather it tries to teach the individual the basic skills necessary to pursue an apprenticeship in automotive mechanics. Following the training, which may last a maximum of two years, the trainee is given assistance in finding a job in the Portland area. During the last few months of the student's training he may be placed in a job on a part-time basis. The student spends a few hours a day at this job and the rest of the day in training classes at the Center. It is hoped that by giving the student a chance to operate in an actual work situation he will gain valuable experience which he will need after graduation.

The second objective of PRMC is to provide the student with a basic education, primarily the G.E.D.* The progran director has set this as a prerequisite to graduation. The student must acquire a G.E.D. before the staff considers him eligible for graduation. PRMC employs teachers in all areas necessary for either passing the G.E.D. exam or receiving a high school diploma. The trainee's educational deficiencies are determined from entrance tests; remedial courses are given the student to make up these deficiencies. Each student has his educational program designed distinctly around his own requirements. He may work for either a diploma or a G.E.D., with most opting for the latter, probably because the students as a whole do not enjoy school much and attempt to get through the educational requirements as easily as possible.

The third objective of PRMC is in the area of general socialization.

*If an individual without a diploma passes a test with a General Educational Development of 1.2 years, he is certified as having the equivalent of a high school diploma. 
By socialization is meant all those aspects of the program which attempt to instill what the Center considers the appropriate and necessary values and attitudes toward work and social life. PRMC has many methods which are aimed at this general goal of socialization. One of these methods is found in the fact that most of the students at PRMC are residents. The Center becomes home for the resident students; they are fed, housed and counseled by the Center staff on a 24 -hour basis. In this way the Center provides, or attempts to provide, a guiding influence over its trainees. Rules and regulations are instituted not so much under the auspices of maintaining control but more as a means of instilling in the pupils the belief in the validity of these rules and regulations. At a general orientation session for incoming students which I attended, Ben Talley, the head counselor at PRMC, explained that one of the important goals of the Center was to teach its pupils the importance of being able to get along with others. As an example Mr. Talley told them that the rule stating that the boys must have haircuts was necessary not because the staff didn't like long hair but because hair length had a great deal to do with employability. In the same vein personal clean1iness is taught as a value in itself rather than as a health measure, although both reasons are considered important by the staff of PRMC. PRMC has a rather elaborate dress code which is rigidly enforced. Again, the dress code is enforced not because of the Center staff's values but ostensibly beca ise the students should learn what is expected of them when they get out into "the world." The staff, in many instances, represent themselves as completely open-minded concerning many of the above mentioned rules, but they enforce them just the same because they believe that these rules are necessary for the students if they are going 
to become "contributing nembers of society." This stance was rationalized to me by Dr. Ri.chard Boss, the Center Director, when he stated that, indeed, change was necessary in many areas of society but the students must first conform to existing standards after which they may work from within to achieve change.

Another, and more explicit, attempt at general socialization is evident in the PRIDE program at PRMC. The goals of the PRIDE program are stated in the Student's Handbook.

This program [PRIDE] is designed to give you the pride that comes from having worked hard and performed productively. The program expects you to receive the following benefits from this program.

1. To develop a sense of discipline and self-esteem.

2. To become accustomed to the idea that hard work produces rewards; in this case, incentive pay raises of $\$ 5.00$ per month up to a maximum of $\$ 50.00$.

3. To increase your understanding of the responsibility of employment (Student's Handbook, p. 17).

As can be seen above PRMC offers a rather complete developmental program. AlI aspects of the individual's Iife are subject to control by PRMC. The Center goes significantly beyond the job training aspects of its program and attempts to deal with those limitations of the student's behavior which the staff perceives to be a hindrance to the individual's employability. The socialization attempts at PRMC duplicate those attempts made in Job Corps camps throughout the nation. It is the intent of this study to gain understanding of how these socialization attempts affect the trainee's perception of his ow abilities and the effects of these attempts on the trainee's ability to deal with the world he is being trained for.

Students at PRMC are paid a salary of $\$ 30$ a month, excluding the $\$ 5$ bonuses they may later receive, with an additional $\$ 50$ per month held 
for them until such time as they leave the program; however, they must remain in the program for at least six months before they are eligible to collect all of the money that has been held. From this thirty dollars the payroll office deducts Federal and State taxes and any fines the student may have accrued during the month. The students are fined fifty cents or a dollar for rule infractions such as unexcused absences from class.

PRMC conducts its operations from two locations or campuses. The main campus is located in downtown Portland and there is another campus, Springdale, about 15 miles east of Portland. The male trainees live at the Springdale campus, and the female trainees live in town a few blocks from the main campus. Classes run all year with the usual school vacations except for summer. Each weekend the students may go home to their families if they receive a pass. PRMC shares much in common with a military establishment including the language; the students go out on pass and on leave and if they do not return in time they are AWOL. For the most part, the student at PRMC is highly controlled and scheduled.

\section{Portland New Careers Project}

The New Careers program in Portland is operated as part of the Concentrated Employment Program (CEP) and is only one of many similar programs throughout the nation funded through the Federal Government. CEP attempts tu place individuals who lack ti aining and/or education into jobs or into training programs which will prepare them for jobs. Organizationally New Careers is operated under the auspices of CEP; however, it has its own director and staff. On entering the program the 
trainee is given a job with a social. service agency at which he works about four hours a day and spends another four hours in regular college courses related to the work he is doing at the agency. The initial phase of schooling may be work towards finishing high school, after which he will go into the college courses. The New Careerist may follow this combined work-study course for a maximum of two years or until the agency hires him on a full-time basis. There are New Careerists in the Portland Public schools as teacher aides, with the state employment division, welfare services and several other government and private social service agencies. The New Careerist training is pre-professional and he is theoretically capable, after finishing the required academic and experiential training, of becoming a full-fledged professional in the agency at which he was originally placed or one similar to it. This professional status, however, is not achieved while a member of the New Careers program. He must puruse his education on his own following his two years with the program. Many New Careerists have been hired by their agencies prior to the end of the two year period of training. The New Careerist's ideal work-study pattern goes something like this; the New Careerist enters the program and is placed with an agency, say the Portland Public School District. After making up any high school requirements he needs he goes into college course work with a major in Education. After two years he is hired full-time by the school and continues his s`hooling on his own until bo eceives a teaching credentjal and becomes a teacher himself. To date no New Careerist has completed this ideal pattern as the program has only been in operation since November of 1.969 ; it remains to be seen whether there will be people who complete this pattern. 
The New Careerist is paid approximately $\$ 350.00$ per month to start plus tuition and books for school. If necessary he is also provided with transportation to and from work for the first month only (until his first pay check is received), day care facilities, and medical services. Each week the New Careerists meet with their developer/trainer who is responsible for monitoring their progress and helps them with any problems they may have with their training. At the time of this study there were three developer/trainers on the New Careers staff and each was responsible for about 20 New Careerists. The New Careers program is organized in cycles. The first group of trainees, Cycle I, began training in November, 1969. Each cycle starts with from 20 to 35 people. The drop out rate of the first cycle was quite high but it has tended to lessen with later cycles. It does, however, remain fairly high because many of the trainees are taking full-time positions with their agencies prior to completion of the program. Currently the New Careers program is training three cycles with a fourth scheduled to begin in the fall of 1971 . The cycles do not begin in a definitely scheduled pattern but depend on dropout rates, placement contracts with the agencies, money available and other contingencies which tend to limit the number of individuals the program can handle.

New Careers is a relatively unstructured program. The New Careers staff help the trainee to resolve any problems he may face at his placement agency or with his classes; aside from this, he is left to fend for himself and render his own decisions. In addition to trainee counseling the New Careers staff maintains a close relationship with the various placement agencies to help them deal with the problems presented by the 
New Careerist in their employ. In the spring of 1970 the New Careers staff operated a practicum for agency supervisors which met each week for three months to work out developmenta1 problems of the New Careerists placed in the agencies. One of the purposes of this practicum was, according to Buzz Willitz, Portland New Careers Project Director, to try to get the agency heads to change thejr thinking about the poor and alter the structural aspects of their agencies to accept them. This is a fundamentally different approach from that followed by PRMC in that New Careers aims primarily at altering the agency to accept the poor rather than at altering the poor to accept the agency. The New Careers program makes no separate effort at socialization as does PRMC; in fact, most of the socializing forces brought to bear on the New Careerist come from his placement agency rather than the New Careers staff. The New Careers staff trust the New Careerists more than PRMC trust their students and as a result does not attempt to control their trainees as does PRMC.

I have now looked at the major characteristics of both New Careers and Portland Residential Manpower Center and will now attempt an analysis of how these two different program designs affect the trainee in his relationships with the respective staff of each program. It is interesting to note here that New Careers has a group of trainees placed with Portland Residential Manpower Center as para-professionals. With this arrengement we have trainees of on: program acting as staff in the other. I will deal with this phenomenon in a separate section after looking at the individual programs. 
CHAPTER IV

FINDINGS

Portland Residential Manpower Center - A Matter of Respect

At a preliminary orientation for new trainees at PRMC given prior to enrollment in the program, the prospective trainees are introduced to the Center. At this orientation the prospective trainees, about twenty of them, are told what is expected of them and given the details on how the program is operated; a tour of the facilities follows. At this orientation session the trainee is told that the Center can train him for a job that he is interested in and can help him find a job once he has been trained. The prospective trainees are told that this is probably their last chance at success in life. They are coming to IRMC because they have been unable to make it through normal channels and that if they don't make it here they would be in trouble. They are told to treat the Center as a second chance and to forget about their past failures; they are starting over here. Talking to these prospective trainees after the session, I found that they expressed hope and a desire to succeed in the program. On the whole they thought the program sounded like a good opportunity to learn something they were interested in. Neil, a 17 year old male, expressed the belief that only at PRMC could he get the kind of training in which he was interested. He said that he had attempted to enlist in the Navy but that he was unable to do so because he lacked a high school diploma. He was referred to the Center by an employment counselor in Portland and was looking forward 
to his stay at PRMC as were most of the other prospective trainees.

On our tour of the installations, I was struck by the signs that are in evidence everywhere. Signs such as "Be an Engine, Not a Caboose" and "Losers Never Win and Winners Never Lose" seek to inspire the student to "push on in the face of adversity." During the tour the prospective trainees meet the teachers and many other staff members who informally welcome them to the program and express hope in their success. Dther students they meet on the tour present the Center as a good place to be and inform the incoming students that all in a11 the program is a good one and that they enjoy it. The predominant feeling of these prospective students after the orientation session is one of optimism and hope in their ability to remajn in the program until they graduate.

I. had occasion to talk with Neil again three weeks after this orientation session and his optimism had begun to fail him a bit. He thought that the rules and regulations of the Center made it analogous to a prison but that he would try to stick it out for a while or until he could pass his G.E.D. test and join the Navy. I found this to be a rather common response of the new trainees to the program. Initially, there was a high degree of optimism followed by a more critical evaluation of the program. This change seems to develop for several reasons.

1) The new student finds that there is more work involved in the program than he had anticipated.

2) The student's activities are controlled much more than he had anticipated.

3) It soon becomes evident that the staff and the students 
do not have as harmonious a relationship as the student had anticipated.

After entering the program the student spends a rather full day. He gets up early, must clean his room or sleeping area, have breakfast and be in class by $8: 00 \mathrm{a} . \mathrm{m}$. He attends classes until 3:30 or 4:00 o'clock. Two evenings a week he is not allowed to leave the Center; one of these evenings is spent with the resident advisor in dorm meetings. (The resident advisor is a staff member who is responsible for maintaining order in the dorm. There are resident advisors on duty twenty-four hours a day.) The other evening is spent cleaning up the dorms. The students are also expected to perform kitchen duties periodically. The new student at PRMC soon learns that he must do a considerable amount of work in the program, much of it not directly connected with his training; he soon becomes somewhat disillusioned and expresses a degree of dislike for these extra duties.

The new student also learns that his behavior is much more controlled than he had anticipated. There are numerous sanctions against much of the behavior the student exhibits. These sanctions are usually fines or the denial of an evening or weekend pass. The student is paid $\$ 15$ every two weeks which after normal deductions comes to about $\$ 13$. If the student has accrued any fines during the preceding two week period these are also deducted from his pay so that it is not unusual for an individual to end up with $\$ 8$ or $\$ 9$ to last him two weeks. Fines are imposed for behavior such as smoking in bed, leaving your living area dirty, being late to class and other such rule violations. The student soon realizes that he must do what is expected of him if he is to enjoy any of his privileges. The staff is very good at using threat 
of denial of privileges to maintain order. When the television broke down in the boys' recreation room the staff informed the students that the TV would not be repaired because the recreation room was being left in an unorderly state every evening. The IV would be repaired only when the students demonstrated their ability to maintain the recreation room in an orderly and clean condition. The students, on entering the program, think of it as primarily aimed at job training and when they are confronted with these extra controls on their behavior they become more critical of the program and somewhat disillusioned.

Finally and probably most important is the fact that the students and staff do not comprise an altogether harmonious group. The new students enter the program with the belief that the staff and students make up a kind of community where they all work together toward a common goal. In actuality there is a strong we-they attitude between the staff and the students. An editorial in the Center newspaper, the Victoria Voice, points out this attitude:

I have been bothered by a few people who have come to me to seek sympathy about how our school is being run. Needless to say I am tired of the bickering about Dr. Boss, Mr. Brown and Mrs. Ayers! These three people have the hardest job to maintain in our school to keep it going. Students have confronted me about Mr. Brown being so cruel, as I see it, he is here to maintain discipline and order for our benefit, if we live in the dorms. It's a tough job, but someone has to do it. I am sure that he doesn't get any big thrill out of what he has to do. Sure there are those that don't like authority but whereever you go there will. always be someone above you. Some students do not like being sick so they go see the nurse. Afterwards they complain because all they got was a few pills. Fine, like one of my teachers said, "If you dnn't like pills you can always have sHors." So take your pick. She is no quack, she knows what she is doing. If she didn't, nursing would not be her profession.

As for Dr. Boss, [the Center Director], I think he is doing the best he can to make this school work. All we need is student cooperation. I've been here almost eight months and I've seen alot of progress in our school. 
I'm proud of the key stafi, teachers, resident advisors, and $\mathrm{Dr}$. Boss. If it weren't for these people we wouldn't be here. And I wouldn't have grown up (Brown, November 23, 1970).

The above editcrial represents a rather wicormon attitude among the students at PRMC. Most of the students, the author of the above editorial notwithstanding, are quite unhappy with the way in which the staff treats them but when questioned about this dissatisfaction they state that the staff has a job to do and that they know better what is good for the students than do the students. Every week the students participated in small group discussion about various topics assigned to the groups. I attended a group run by a Miss Hall; in virtually every session I attended the discussion would invariably come around to student-staff relations. The group would be concerned by the staff's seeming lack of respect for the students. The students in Miss Hall's small group felt that the staff looked on them as children who had to be supervised and controlled constantly and they were quite unhappy with this treatinent. This concern of the students is reinforced in several sections of the Seminar for Improvement booklet. Students were sent in discussion groups with a staff member to discuss various assigned topics. The topics usually covered problematic aspects of the program and the discussion groups were asked to seek solutions to the problems presented them. One of these topics concerned rules for staff members and the students were asked to name what they thought should be the three most important rules for staff wemuers and to list the proper punishment for violation of these rules. The three rules mentioned most by these groups vere:

1) "Treat al1 students as adults and equals." 
2). "Keep student confidences confidential."

3) "Obtain permission from student before going through personal possessions," (Seminar for Improvement, p. 10). All but two of the fifteen rules proposed were concerned with staff respect of student rights. Two punishments proposed with overwhelming support were:

1) "Staff fined same as students."

2) "Staff to be called before Student Review Board," (p. 10). These punishments attempt to subject the staff to equal treatment with the students and respect is again a factor. For another topic the groups were asked to "list five things that a staff member does when he communicates well with students." The most mentioned things in this category were:

1) "Listens."

2) "Helps with problems."

3) "Understanding and willing to talk."

4) "Put themselves on student level and talk their language."

5) "Friendliness and being genuine," (p. 23).

Under the same topic the students were asked to list five things which make communication difficult. The five most mentioned categories were:

1) "Not enough 1 istening or understanding and explaining."

2) "Too busy to help student."

3) "Inconsiderate, Jacking in respect."

4) "What students have to say isn't important."

5) "Militaristic attitudes and disciplinary actions," (p. 10. The Appendix 1ists all of the proposals given for the above topics.). 
Based on the above examples it can be seen that the students feel that two-way respect should be, but generally isn't, a necessary element of the program. The students are bothered by this because they believe. that the staff should respect the student: as well as demand respect from them.

The staff members are of the attitude that the students must learn to respect authority because they are going to be subject to it when they get out of the program. This is the same attitude Glenda Brown expressed in the editorial above and it is a strongly held attitude on the part of the staff from the Center Director on down. The staff members believe that the students must learn to order their lives in such a manner that they will be able to succeed once they leave the Center. The staff members define the students as being unable to make decisions and unable to determine what kind of behavior is best for them; this definition is then used as a reason to maintain strict control on the students.

One examnle of this definition of the students' ability to make decisions took place during Miss Hall's small group session at the Center. Miss Hall, the staff leader of the group, told the group members that Mr. Talley, the head counselor, wanted students selected as group leaders. Miss Hall interpreted this to mean that she should select the group leader rather than have them select their own. She explained that it would take too much time to have the students select a leader whereupon she appointed a leader. The appointed student proceeded to open the discussion and this it turned out was the extent of student leadership of Miss Hall's small group. During this group meeting Miss Hall continued to guide the students and placed most of the questions before them. 
During the following weeks Miss Hall never again selected a group leader; indeed, the subject of student leadership of the group was never broached again. The point to be made is that Miss Hall defined the students as being unable to carry on a discussion without her constant guidance. This is, according to my observations at the Center, the common behavior of the staff members. The students are constantly told that they don't receive more freedom because they don't know how to use it when they receive it. The staff then points to the students' inability to take care of their rooms and recreation areas as an example of their being unable to take care of themselves. The students are led to believe that they will receive respect when and if they follow the rules. The staff members reward behavior which conforms to the expectations they have set for the students; indeed, in my initial interview with the Center Director, he defined learning as a "change in behavior" (July, 1970). The students soon come to believe in this and verbally blame themselves for the sanctions imposed on their behavior by the staff. They learn that the sign that tells them to "Be an Ingine, not a Caboose" is a contradiction of the kinds of behavior the staff expects from them. The students are not taught to act in a multi-faceted world but to react to a predetermined set of stimuli. The students cannot truly act because they are not presented with any behavioral options. Rather than presenting the world to the students as problematic the staff presents them with a world that demands only a certain type of behavior and insists that their success in the world depents on how well they can learn the appropriate behavior. Though the students verbally accept this view of the world they react to it with feelings of distrust, doubt, and dissatisfaction because they had entered the program to expand these behavioral options, 
not to limit them. The fact that the students verbally accept the staff conception of the world merely adds support to the staff's position.

The idea of behavioral options is worthy of further consideration, since it is an essential factor in the trainee's adjustment to the program and his ability to cope with problems as they arise. PRMC has imposed a rather restricted range of acceptable behavior. Students are not given opportunities to choose a course of action of their own; this can be seen in Miss Hall's small group when she would not even allow them to choose a group leader. The only problems that the Center recognizes are those problems presented when the students deviate from this predefined course of action. The Center considers its primary duty to be one of keeping the students following this course. Another case in point is the fact that the Center held its Seminar for Improvement not necessarily because it was important in itself but because they wanted to remove the students from the Portland area during an American Legion Convention. The introduction to the booklet, Seminar for Improvement, explicates the main reason for holding the seminar.

In late July and early August, it was brought to the attention of the Center Director that the American Legion Convention was to be held in Portland, Oregon, during the last few days of August and the first few days of September. The Center Security Chief began meeting with local authorities when it became known that this convention was to attract a large number of young people, "hippies and yippies," who planned a confrontation with the American Legion. It soon developed that this confrontation was being viewed upon as a very serious problem for Portland and more specifically a problem for the Portland Residential. Manpower Center. American Legion hsadquarters at the Hilton Hotel and National Guard units housed at Lincoln High School placed the Center Administration Building directly between "the line of fire." The Center Director, along with the help of key staff . . decided that something had to be done (p: 1).

It is also instructive to note that immediately following the "Seminar 
for Improvement" many of the students were quite happy with what happened there. They felt that they had brought out many problems that were not recognized prior to the seminar and thought that the staff would make an attempt to alleviate some of these problems; however; after a few months the students began to believe that the staff had no intention of altering the program in ways based on the results of the seminar. The staff did remove fines as punishment for a short while but reinstituted them when they felt that the students were taking advantage of the situation. Very few changes have taken place as a result of the "Seminar for Improvement" and student-staff relations have changed very little since the Seminar. In this and in other ways PRMC limits the behavioral options of the students under its control and the students are forced, providing they don't leave the program altogether, to behave as the center directs them to.

The all encompassing guidance the Center imposes on its trainees is very much in line with the "culture of poverty" theory presented in Chapter I. PRMC, by its philosophy and actions, believes that the trainees in its care lack the desires and values to be successful in a given occupation so the Center attempts to instill the appropriate desires and values in the trainees by making their decisions for them. As stated above the students verbally accept this, but when questioned they don't quite understand it. They came to the program to learn a skill and are unable to understand why they have to put up with all of the seemingly extraneous controls they are subjected to, hence they become somewhat resentful, distrustful, and dissatisfied with many aspects of the progran. 
New Careers-A Matter of Structure

The problems faced by New Careerists are fundamentally different from those faced by the trainees at PRMC. Where PRMC severely limits behavioral options the New Careers program expands them. The New Careers program is lacking in structural controls almost to the extent that PRMC maintains them. The New Careerist is given as nuch freedom as he is willing to take in organizing his own program and his success in the program is much more dependent on his own ability to run his affairs than on the program's ability to demand a given set of actions from him. About the only external controls placed on the student are:

1) He is expected to make progress in his education.

2) He is expected to remain with his placement agency. The staff members believe that their most important job is to help the placement agency accept the New Careerist rather than reforming the New Careerist. The Director of the New Careers Project informed me that his most difficult task was getting the placement agencies to accept the New Careerist as a pre-professional rather than a cheap labor. The New Careers practicum for agency supervisors was an attempt to achieve this goal. The practicum was designed to develop training programs for the New Careerists that were meaningful, workable and that allowed the trainee maximum opportunity for advancement. The staff members of New Careers had hoped, through the practicum, to remove those aspects of the trainees' jobs in the placement agencies which might hinder his development and advancement at the agency.

During one of the early sessions of the practicum a considerable amount of time was spent attempting to decide what kinds of job titles the New Careerists should have. The members of the practicum felt that 
"aide" was a bad title because it had a connotation of a dead-end position. Pre-professional was decided on as the best possible title because it signified the mobility which was an important aspect of the training program. The New Careers staff also attempted, during this practicum, to move the agencies towards the development of an occupational ladder which could be presented to the New Careerist to show him just what was expected of him and the progress he could make during the training period. After a few weeks of development Vocational Village, a training program much like PRMC, presented a finished job training description for the position of "Cooperative Work Experience Coordinator" which is a staff member who helps the trainee at Vocational Village find a job after he completes his training period. This training description was broken down into a set of tasks which the New Careerist was expected to complete if he was to advance in the program. There was some discussion concerning these tasks because some members of the New Careers staff were afraid that the New Careerist may perceive of these tasks as hindrances rather than as steps toward a goal. They wanted the placement agencies to make certain that the New Careerist recognized them as steps that he could take without too much difficulty. It was decided that the agencies would go over each step with the New Careerist involved and encourage him to seek advice whenever he had trouble with his training program. In this manner the New Careers staff works closely with the vario:s placement agencies in an attempt to make the New Careerist's adjustment to the agencies as easy as possible.

The New Careers Project has no formal programs designed toward the goal of general value socialization such as those at PRMC. This is not to say that socialization does not take place in the program, only 
that the program does not recognize the need for socialization attempts outside of those inherent in any type of job or professional training. The New Careerist is never told that he should change or develop his attitudes and values toward work; rather, the New Careers staff acts as if the trainee already has the appropriate attitudes and values and lacks only the training and education necessary to fulfill them. The staff attempts to give the trainee the trajning and education he needs and otherwise leaves the trainee to pursue his own program. The primary agent of socialization for the New Careerist is most likely his placement agency. Many of the New Careerists I have talked with during the course of this study were getting very involved with the placement agencies and were anxious to go to work for them full-time. One of the New Careerists, a white, male working at Vocational Village administering various psychological and educational attainment tests there, was becoming very interested in these tests. When asked why the tests were important he stated that they were needed to weed out those trainees who might present a problem to the program. This New Careerist was beginning to identify with the placement agency goals and beliefs rather than the New Careers goals and beliefs as the New Careers staff very strongly believes that these psychological tests are of little value and may well weed out those individuals who need the opportunity the most, because many of the poor may exhibit psychological inadequacies as a result of theit lack of opportunities in the past rather than as a result of inherent psychological problems.

In the same vein many of the New Careerists who work for the public school system as Teacher Aides have become exceedingly interested in their jobs to the extent that they spend a great deal of time trying 
to do a better job for their students and attempting to develop new educational programs at some of the schools where they work. For these people the New Careers staff plays a very small role in their training once they get involved in their training. These examples tend to support the idea that the primary agent of socialization for the New Careerist is his placement agency rather than the New Careers program itself, but this presents us with a problem for the New Careers program that is not anticipated by either the New Careers staff or by the program designers. If the New Careerists begin to identify with the placement agency goals rather than the New Careers Project goals, how will this affect the New Careers project's attempts to alter the placement agencies' views of the poor? I will deal with this problem in some detail when I talk about the New Careerist as staff in other training programs. The lack of clearly defined rules and regulations in the New Careers program and the expansion of behavioral options is an exceedingly important variable to be considered when talking about trainee response to program design. The New Careers program allows the trajnee to organize his own life and, to a considerable extent, his own training program. The New Careerist takes his college courses through the Division of Continuing Education at Portland State University and it is up to him to successfully complete his courses. Most of these courses are taken with other New Careerists, which gives him some support, in that he is not simply thrown into open enrollment classes. The New Careerist is not told what courses he must take but is allowed considerable freedom to take courses which he feels are important for the training he is receiving. The New Gareerist pursues his education much the same as any college student. He has a major with certain requirements 
and he also has a number of electives he can take. Many of the trainees have not taken as many courses as they should have and wind up with a deficit toward the end of their two years $i_{i n}$ the program, at which time they must either overload themselves with courses or hope that the agency will hire them full-time and continue their educational training at their own expense.

This lack of clearly defined structural controls affects New Careerists in various ways. Some of the trainees attempt to use this lack of structure to their own ends. This attempt to use the lack of structure is quite noticeable in the classes the trainees take. Many of these people attempt to take advantage of the instructor's willingness to demand less from the New Careerist than he might from open enrollment students. These students become quite good at manipulating this willingness of the instructor to their own ends by not reading what should be read or by not doing assignments that should be done. They realize that they will probably receive a passing grade because they are not expected to do as well as a regular student. Some of these trainees have shown considerable skill in "jiving" the instructor. Other New Careerists are unable to do the work and are unable to "jive" their way through classes. For these people New Careers becomes an exceedingly difficult program. One student in an Introduction to Sociology class consistently failed exams and had a great deal of trouble doing nis assignments. He sought nelp from the instructor who gave him as much time as he could spare. He asked me, at one of the class meetings, if I could tutor him because he was having trouble understanding sociology and I spent some time talking with him and 
attempting to help, all of which was to no avail. This individual then began to skip the classes which compounded his problems and I have no doubt that he will eventually leave the program without any kind of training which will help him get a job elsewhere.

For most other New Careerists the program seems to be very appropriate. In their classes these people begin rather unsure of their roles as students but soon begin to develop their skills. During the first quarter of course work the students turn in papers which are handwritten and quite disordered but by the time they have completed the second quarter their work improves considerably; more papers are typed and very readable with some of them excellently done. These people feel that New Careers has helped them considerably and that the program is excellent. They like the work at their placement agency and feel that they are making progress.

A11 of the above New Careerists, moreover, feel that the staff is on their side. The underlying suspicion and distruct of the staff that is in evidence at PRMC does not appear to be a factor at New Careers. When they have problems the New Careerists do not express distrust in the staff; indeed, if they blame the staff at all it is because the staff does not impose enough structure on them. Some of the New Careerists freely admit that an unstructured program such as New Careers is very difficult to succeed in because they are expected to learn many abstract types of skills with a mininum of staff incerierence; therefore, rather than believe that the staff does not trust them many of the New Careerists believe that the staff trusts them too much. In many cases this lack of structure reduces the control the New Careers staff has over the program. Most of the structure in the program is most likely found 
in the placement agency. The New Careerists find that it is the placement agency that guides their behavior rather than the New Careers staff and many of the New Careerists organize their training around placement agency expectations.

A problem faced by many of the New Careerists who have trouble succeeding in the program, I would estimate around $30 \%$, is the lack of coordination between his job at the placement agency and the college courses he takes. Many of the trainees have had trouble with school for some time and do not relish the idea of returning. School, for many of the trainees, has lacked meaning and they could see no relation between school and learning the skills necessary to obtain a good job. New Careers has attempted to solve this problem by offering the student classes directly related to the work they are doing at the placement agency but I am not sure that the relationship is clearly perceived by the New Careerists. The courses offered are usually standard college courses and are taught by people who have no connection with the placement agency. These teachers do not attempt to align the course work in their classes with the New Careerist's work at his placement agency. The New Careerist may, therefore, do quite well at the placement agency but poorly in his class work. In this case he will go to work for the placement agency as soon as he is offered a position, but the job he takes at the placement agency turns out to be a rather dead-end, nonprofessional $j \cap b$ because he lacks the eduration to go beyond the position he held as a New Careerist. One such individual who was a resident advisor at PRMC accepted a full-time position with PRMC as a resident advisor and subsequently left New Careers. The position as resident advisor at PRMC does not pay much and there is 1ittle opportunity for 
advancement and the skills he acquired as a resident advisor are not sufficient to acquire a job elsewhere. New Careerists may be a little overanxious to go to work full-time for the agency before they have finished their training as a New Careerist. This is, in large part, a result of the lack of coordination between the New Careerist's placement agency job and his college training. This problem, coupled with lack of structure in the New Careers program, strongly affects the success of the program. Some trainees who might otherwise succeed at New Careers fail very probably because of these two inadequacies of program design. The opening of behavioral options and the widening of opportunity attempted by New Careers has been a positive good to most of the New Careerists but has not worked well for others. To sum up, student-staff relations are generally excellent at New Careers. The New Careerist has a great deal of trust in the staff and feels that they will stand behind him in any battle he may have with his placement agency or with his teachers. Most of the participants. feel that the opportunities for advancement in the program are good and that success or failure is largely dependent on their own desire and abilities. Those who are having a diffucult time progressing in the program still maintain a trust in the staff at New Careers and feel that their difficulties with the program are a product of their own inadequacies or that the staff has not imposed enough order on the program to keep them headed in the right direction. They feel that the developmental steps in the program are too ill-defined and that the program should lay out its expectations clearly and concisely so that the trainees will know how much progress they are making. 
The New Careerist as Staff at PRMC

During one of Miss Hall's small group sessions at PRMC the subject of clothing leiters* came up and the studunti were angry that they weren't getting them on time. They argued that a Miss Nelson was not getting the clothing letters out on time and that the students had been counting on these letters. One of the students in the small group said that Miss Simpson had a lot of work to do and only so much time to do it in so they shouldn't blame her. It turned out that Miss Simpson was a New Careerist who had been placed with PRMC. I was struck with the fact that the students referred to her as Miss Nelson and tended to put the New Careerists at PRMC in the same group as the rest of the staff. Further investigation uncovered that there were several New Careerists at PRMC and that they were all deferred to as staff by the students. What effect did this deference have on the New Careerists and how did they adjust to it? Here was a case where a trainee in one training program was staff in another. If these New Careerists as staff at another training program identified with the goals of this program as opposed to those of the New Careers program then the ability of the New Careers program to alter the structure of the agencies at which their. trainees were placed would be impaired because the New Careerist may well side with his placement agency in matters of disagreement with the New Careers program. Also the idea that the poor would be better able to give service to the poor because of their background would be a bit

*After the student has been at PRMC for 60 days he is eligible for a clothing letter which enables him to purchase clothes from selected stores in the Portland area. This allotment is in addition to his regular pay check. 
naive if those poor identified with the agency goals rather than their background experiences. It may well be the case that the New Careerists are developing the same bureaucratic attitudes as those prevalent in their placement agency and no longer identify with the problems of the poor. Some evidence in support of this view can be found in the Portland New Careers Project. The example, mentioned above, of the New Careerist who administered tests to Vocational Village trainees to weed out those who might present a problem to the program is a case in point. This individual thought that these tests were important to insure success of the program in spite of the fact that the New Careers staff are strongly against these tests and do not believe that success is a primary criterion for a training program. Another New Careerist, who works as a resident advisor at PRMC, believes that strong controls are necessary to keep the "kids" in line when the New Careers staff does not recognize these controls as being necessary. These examples indicate that very possibly one of the main goals of the New Careers program, as set down by Pearl and Riessman (1965) above, is not being fulfilled, that goal being to give social services a humanistic rather than bureaucratic approach. New Careers may be training people to become the same middle-class bureaucrats that the New Careers staff is against. The program has not been operative long enough nor has it processed enough people for an answer to this possible problem and there is evidence from another program, to be cited shortly, which tends to repudiate my suspicions. The cases I have cited may well be exceptions and it can be argued that these people were middle class oriented to begin with, hence had not changed attitudes at all during the training. 
R. Frank Falk in a study of a New Careers program in Minneapolis believes that the New Careerist does indeed maintain his identity with the poor.

New Careerists, however, do not change so systematically that they represent nothing more than the creation of another group of middle-class professionals. The life experiences of these individuals who have been poverty residents in the past stay with them. They are able to continue to relate to the low income community and to attempt to make improvements within the human service programs which serve their ow communities. The New Careerist does tend to become slightly more "professionalized" in his delivery of services to members of the low income community. But he does not become so professionalized that he sees himself as radically different and unrelated to the low income community. (Falk, 1969, pp. 25-26. This study came to my attention only after I had completed ny own data collection.)

One reason for the possible differences between Falk's findings and my own could well be the selection processes in the two programs. If the Portland New Careers people are selecting only those individuals who might be successful because they already exhibit middle-class attributes then the chances of selecting people who would fail to relate to the poor once they have left the conditions of poverty may be stronger. If people are agency centered prior to entering the New Careers program then they will not have to change at all in order to exhibit the bureaucratic tendencies I have seen. My examples are to few to seriously propose that the New Careers program is training more middle-class bureaucrats rather than social service workers who better understand the people they are serving; however, the possibility that this is true should not be overlooked, because it is of great importance to the philosophy behind the New Careers program. More study is required of the program here in Portland over a longer period of time. It would be important to find out what the New Careerists are doing a year or two 
after they leave the program to see what kinds of changes have taken place in the New Careerist's attitudes toward the poor. 


\section{CHAPTER V}

\section{CONCLUSIONS}

Sociologists have long been proposing theoretical models of different aspects of social life. The nature of the discipline is such that these theoretical models are an essential part of the work of sociology; however, when these theoretical models are used as a basis for social service programs the designers of these programs are generally not sociologists. This gives the sociologist an added responsibility, primarily that of looking at the consequences of the theoretical model he has proposed. In the case of the poverty theories dealt with above, the social scientists who were responsible for these models have been largely unaware of the consequences, for the people being served, of these models when they are translated into action programs. The people who have designed these have accepted ccrtain theoretical noticns of poverty but have generally failed to look at the effects of these notions on the people the program is designed to serve. Both the "Culture of Poverty" model and the "Closed Opportunity Structure" model show some rather serious shortcomings once they become the basis of a job training program. I have attempted in Chapter IV to explicate these shortcomings and supply examples showing the effects of these shortcomings on the people being trained.

Portland Residential Manpower Center is designed primarily along the lines of the "Culture of Poverty" model. Because the "Culture of Poverty" model maintains that the poor have values and attitudes which 
are not conducive to success, PRMC attempts to give the trainee these values and attitudes, but, in so doing, leads the trainees to distrust the staff of PRMC. Rather than opening up opportunities for the poor, PRMC severely limits the opportunities by not granting the trainee the chance to pursue a course of action he has chosen for himself. It is true that the PRMC trainees can choose the general area in which they get their training but this is the only choice they are accorded. The trainee at PRMC must fit the mold that has been made for him if he is to succeed in the program. At their first orientation meeting the prospective trainees are told that they have made mistakes in the past and that they are about to receive their last chance to succeed, hence, by PRMC's definition, the trainees have been unable to decide for themselves what their individual needs are so PRMC decides for them. This belief in the inability of the trainees to decide for themselves is in concurrence with the general notions of the "Culture of Poverty" mode1. PRMC shows clearly the possible ramifications this model has on the poor when it is used as a basis for a job training program. "Culture of Poverty" theorists may disagree with the use to which their model is being put by PRMC because of the lack of behavioral options given the trainees at PRMC; however, the logical conclusion to be drawn from the "Culture of Poverty" model is that the poor are unable to exercise behavioral options because of their cultural background. The restriction of behavior options is, therefore, a consequence of the "Culture of Poverty" model and is, presumably, an undesirable consequence. Job training programs for the poor should expand those options rather than limit them and "Culture of Povercy" theorists would agree, but what they haven't recognized is that the new values PRMC is attempting to 
instill in the trainees offers them no more behavioral options than did their old values. It could be argued, of course, that if the trainee at PRMC completes high school and learns the basic knowledge necessary for a skill his behavioral options have been widened and this might

- be true if it were not for the fact that PRMC goes significantly beyond skills training by attempting to tell the trainees how to dress, how to talk, how to think and generally how they should run their lives. Because of these general socialization attempts most of the students are interested primarily in getting their time in and getting out of the program. The trainees are thankful for the opportunity to learn an occupation and to finish high school because they realize that these things will expand their behavioral options; however, the attempt to impose extra socialization strategy which goes beyond job training tends to negate whatever value the other training may have because it increases the alienation of the already alienated students in the program. The student comes to believe that he must do as he is told to avoid failure and that he has relatively little power in the matter. He has been a failure before entering PRMC and is told that the only way he can avoid failure is to follow the dictates of the program. PRMC, then, limits behavioral options because the students are given no alternatives to choose among. There is only one way to achieve in this society and PRMC proposes to lead its enrollees in that direction.

The expasion of bebavioral options wolld be difficult to achieve given the assumptions of the "Culture of Poverty" model as set forth in Chapter I because the model implicitly assumes that there is a correct, functional, and acceptable hehavior conducive to escaping from poverty and that the poor do not exhibit this behavior; therefore, they must 
learn it and PRMC attempts to teach it to them. In essence, this subjects the trainees to the same situations they were in prior to their enrollment at PRMC in that they still lack control over their own life and the trainees rebel against this continued control placed upon them by others.

New Careers presents a different problen which in many respects is the opposite of those at PRMC. The Closed Opportunity Structure model does not see the poor as being unable to control their own destiny; rather it sees them as not having been given the opportunity to control their own destiny. A training program should, therefore, be designed so as to give the poor this opportunity and New Careers is an attempt to do this; however, the program runs into problems in that the program fails to supply the trainees with any guidelines to follow in their training. Structural controls are missing in New Careers and the trainec is left on his own. The problem of limited behavioral options which was present at PRMC is not present at New Careers; however, some of the trainees are unable to capitalize on these behavioral options because they are unaware of the options New Careers has opened for them. Most of the New Careerists appear capable of managing the program quite well, but some of them have a great deal of difficulty with the program primarily because of this lack of structure. It would, therefore, appear that maximization of behavioral options is not in itself sufficient for many of the poor and that those people wh have difficulty progressing in the program would do better if they had a well-worked out, wellplanned program to follow. This is not to say that they must follow the program, rather that they could do so j.f they found it necessary. Some of the New Careerists have pojnted this out to me and feel that 
many of those who have difficulty in New Careers should be in a program which does not purport to train professionals. Professional training is generally an unstructured kind of training and relies on the trainee's initiative and desire to succeed in the professional training of his choosing. New Careers basically follows this same formula in that the program assumes that the initiative and desire are inherent in all of their trainees, but many of the trainees lack the initiative and desire to pursue a professional program on their own. Just as many of the nonpoor would lack the initiative and desire to pursue a professional career and would have the same difficulty succeeding in New Careers as some of the poor are having. The New Careers staff has, in a limited way, recognized the problem presented by the lack of structure and the attempt, with the placement agencies, to develop clear and precise training descriptions has been a step toward establishing guidelines for training; however, the New Careers staff has little influence over the placement agency and can only hope that the agencies will continue to develop these training procedures to help the trainees understand their obligations and alternatives. In a similar vein overcoming the lack of coordination between class work and the agency job is crucial if the program is to succeed for a larger percentage of the trainees.

It would appear that neither program represents a complete answer to the problem of job training for the poor and that neither of the theoretical models on which these programs are based can be considered as a complete and wholly accurate explanation of poverty. Rather, the poor appear to be as varied as other classes in the society and any single program based on certain conceptions of poverty is bound to fall short for some of the poor. Whereas PRMC is overly structured, New Careers 
suffers from the lack of structure; whereas PRMC fails to give the trainee any real behavioral options, New Careers expands these options but some of the trainees are unable to take advantage of them; whereas PRMC assumes that the poor have no organizational abilities of their own, New Careers assumes that they have more than they do.

The solution to the problems I have presented above might appear to be somewhere between the two programs, but that solution would, of course, be too simplistic. New Careers does work well for many of the poor and for these people additional structural controls are unneeded. But for those who either shouldn't be in pre-professional training or who are not really interested in social service work, but who have entered the New Careers program because it pays fairly well and offers a relatively well paying future with some semblance of prestige, New Careers is not the answer. PRMC, on the other hand, offers little to recommend it. The training received is limited and the trainee must continue training after he leaves the program if he is going to acquire a truly saleable skill. The overly tight controls placed on the trainees do little to boost their self-confidence. It would seem that the only beneficial aspect of PRMC is that it gives the trainee a place to live for two years at which time all of them have become older and can join the Navy as Neil plans or can find a job easier. Many of the trainees at PRMC are under 18 years of age and have trouble getting work because of age; hence, PRMC is a way for them to at least sit out that two years and, who knows, they may just succeed in spite of the program.

A program that may be successful for many of the poor may well operate in conjunction with New Careers but be designed to train people 
for skilled trades rather than as pre-professionals. It might well be a basic apprenticeship program in several skilled trades but with extra support services not found in apprenticeshif programs generally. Thest support services should consist of transportation, if needed; counseling services; high school completion; day care and medical and dental aid. The program should be so designed that the trainee always knows where he stands and the progress he is making. Pay should be adequate with raises given periodically. This type of program may succeed for some of those people for whom New Careers is not a valid option.

This study does not seek to present a final answer to how training programs should be designed; rather it has been aimed at showing the dangers inherent in any program that assumes certain notions about the people they purport to help. The findings presented above indicate that people do not always conform to our assumptions about them and that these assumptions can be and are a factor in the inability of these programs to succeed with many of the people who partake of their services. Also, and most important for sociology, it points out the need for sociologists to examine the consequences of their model building. Sociologists must be aware of how their theoretical models and discoveries are being applied. This plea is not uncommon to physical scientists who are raked over the coals daily for failing to take into account the dangers their discoveries have wrought on mankind, but it is new to theoretical sociology. It may, in the long run, be fortunate that the discoveries of sociologists are not held in awe by policy makers in general and that many of these people do not take sociology seriously, hence, have not made many strong attempts to institute the changes sociologists often invite in their theoretical models. 
Naturally, further research is needed. This study was designed as an exploratory study and as such seeks to point out possible areas for further research. Further study should be undertaken with other New Careers programs and other Job Corps centers across the country to determine the applicability of my findings in Portland to similar programs in other areas. Also, the operationalization of the theoretical models into observable behavior should be made more explicit than this study has attempted to do. I have concentrated on student-staff relationships as a rough operationalization of the theoretical model behind each of the prograns but student-staff relations in themselves are not complete. Student-student and staff-staff relations might be explored to offer a more complete picture of the programs under study. Interviews with students who have left the program or have completed the training may also provide further information concerning the effects of program design on the trainee.

The notion of behavioral options which I have used in this study must be developed further as it is an important variable, not only for the success of the program in terms of whether or not the trainees complete the program, but also in terms of the general development of the trainees as acting, responsible and thinking human beings. I have attempted, in a preliminary way, to show how the theoretical model behind a training program affects the trainee but further research is needed to point out more specific and detailed ramifications of these theoretical models. 
Brown, Glenda. Editorial in the Victoria Voice, a student newspaper at PRMC, October, 1970.

Coleman, James S. 1966. Equality of Educational Opportunity. Washington, D. C.: U. S. Department of Health, Education and We1fare.

Davis, Allison. 1949. "Child Rearing in the Class Structure of American Society," in The Family in a Democratic Society. New York: Columbia University Press.

Gurin, Gerald. 1968. Inner-City Negro Youth in a Job Training Project. Ann Arbor: Institute for Social Research.

Harrinton, Michael. 1962. The Other America. Baltimore: Penguin Books.

Lewis, Oscar. 1959. Five Families: Mexican Case Studies in the Culture of Poverty. New York: Basic Books.

Lewis, Oscar. 1968. "The Culture of Poverty," in Blaustein and Woock, Man Against Poverty: World War III. New York: Vintage Books.

Liebow, Elliot. 1967. Tally's Corner. Boston: Little, Brown and Company.

Merton, Robert. 1968. "Social Structure and Anomie," in Merton, Social Theory and Social Structure. New York: Free Press, pp. 185-214.

Miller, S. M., Riessman, F. and Seagu11. 1965. "Poverty and SelfIndulgence: A Critique of the Non-Deferred Gratification Pattern," in Ferman, et. al. Poverty in America. Ann Arbor: University of Michigan Press, pp. 285-301.

Miller, S. M., et. al. "Creaming the Poor," Transaction, Vo1. 7. No. 8., June, 1970, pp. 38-45.

Moynihan, D. P. 1965. The Negro Family: The Case for National Action. Washington, D. C.: U. S. Department of Labor.

Pearl, A. and Riessman, F. 1965. New Careers for the Poor. New York: Free Press. 
Portland Residential Manpower Center. Seminar for Improvement. A report prepared by Richard D. Boss, Center Director, October, 1970.

Portland Residential Manpower Center. Student's Handbook.

Schneider, L. and Lysgaard, S. 1953. "The Deferred Gratification Pattern: A Preliminary Study," American Sociological Review, 18 (April, 1953), pp. 142-149.

Seligman, Ben B. 1968. Permanent Poverty: An American Syndrome. Quadrangle Books, Chicago.

Weller, Jack. 1966. Yesterday's People. Lexington: University of Kentucky Press. 


\section{APPENDIX}

\section{RESULTS OF TWO GROUP MEETINGS DURING \\ "SEMINAR FOR IMPROVEMENT"}

Objective: If you were to write a Discipline Manual for Staff, what would your three most important rules be? What would be the punishment for violation of these rules?

RULES*

1. Address student by proper name.

2. Treat all students as adults and equals.t

3. Keep student confidences confidential.t+

4. Show no favoritism.t

5. Obtain permission from student before going through personal possessions.t+

6. Leave students alone during free time.

7. Keep communications lines open.t

8. Individual abuses of authority.

9. Practice what they preach.t

10. Counsel with student before recommending termination.

11. Be considerate and understanding.+

\section{PUNISHMENT**}

Staff fined same as students.tit

Staff to be called before Student Review Board.+t+t

Appear before Dr. Boss.

KP or Dorm cleanup.

Take a leave to think over whether they want to keep their job or not.

Note: + sign means that this item was brought up more than once during the committee meetings. For example, 6 pluses means this item was brought up 7 times.

*Results are typed just as they appeared, including mistakes. 
12. General lack of organization in

all departments.

13. Buck passing.

14. Racial prejudice.

15. Lack of tact.

Objective: List five things that a Staff member does when he communicates well with students (good qualities).

List five things that a Staff member does which makes communication with students difficult (bad qualities).

GOOD QUALITIES

They come up with better ideas:

Some make you relaxed when you talk to them.

Proper communication on part of staff gives you more confidence in that member.

Less disappointment accrued from good communication

Trouble makers are brought out into the open.

Listens.HH+

Helps with problems.+H

Takes time with students.

Some staff do take time out for problems.

Good appearance.

Understanding and willing to talk.++

\section{BAD QUALITIES}

Not enough listening or understanding and explaining.+H+H

- Promises without fulfillment.

Tell us one thing - they do another - leave us insecure.

Change mind too easily promise one thing - change don't explain.

Guilty before given a chance to prove innocent.

Teacher leaves subject before it is completely explained not enough individual communication on subject.

Too busy to help students.+H

Inconsiderate, lacking in isspect.H HHH

Staff constantly "guarding" military atmosphere.

R.A.'s too busy to care about student problems.

What students have to say isn't important.H 
Friendliness and being genuine.t

Not revealing what is told in confidence.

Involvement .

Put themselves on student leve1

talk their language.++

Always being available to students having plenty of time to listen to

them.

Show importance of student.

Explains "why" when telling a student to do something.

Observe the Golden Rule.

Talks on a Man to Man basis.

Doesn't hide behind authority.

Has sense of humor.

Motivates you to learn, not just order to.

Available to just rap occasionally.

Many staff are insecure, afraid to

help too much or side with student for

fear of being fired.

Some staff will listen.t

Some understand your feelings.t

Share their wisdom and experience.

They try to relate to you.

Being compassionate.
Staff preaches to students.

Staff not informed or well

organized.t

Staff power plays.

Taking persons' feelings out on students.

Talks about his own problems.

\author{
Makes snap judgments.+ \\ Junps to conclusions. \\ Boring - repetitious. \\ Isn't really interested. \\ Militaristic attitudes and \\ disciplinary actions. $H$ \\ Is too job conscious. \\ Betrays a confidence.t \\ "I'm paid to do this." \\ Don't mind their own business. \\ Hear only what they want to.
}

They make up rules that we don't know until we violate them.

They use their titles as a hasis for being rude to students.

Turns student OFF.

Closed mind attitude.t

Lacks dedication to job and students. 
Keeps conversations confidential.

Good instructors at Manpower.

Shows patience and interest.
Student should be allowed to go home with staff, not just on-the-job acquaintance. 